\title{
A review on soil potassium scenario in vertisols of India
}

\begin{abstract}
Potassium is an essential element for plant growth and production. The Vertisols are generally rich in available potassium reserves for supplying potassium to plant. In present agriculture scenario the negative balance of potassium goes on increasing because crops remove more $\mathrm{K}$ than $\mathrm{N}$ and $\mathrm{P}$. Under such condition there is need to focus on $\mathrm{K}$ fertility status of soil. On the other hand, there is an anomaly regarding crop response to applied potassium in some Vertisols of India. This review paper provides information important to the understanding of soil potassium status and its behavior in Vertisols
\end{abstract}

Keywords: vertisols, potassium, potassium status of India, fertility

\author{
Volume 2 Issue I - 2018 \\ Priya P Gurav, ' SK Ray, ${ }^{2}$ PL Choudhari, ${ }^{3}$ AK \\ Biswas, ' AO Shirale' \\ 'Division of Soil Chemistry \& Fertility, ICAR- Institute of Soil \\ Science, India \\ ${ }^{2}$ Principal Scientist and Head, ICAR-NBSS\&LUP, India \\ ${ }^{3} \mathrm{PhD}$ Scholar, India
}

Correspondence: Priya Pandurang Gurav, Scientist, Division of Soil Chemistry and Fertility, ICAR-Indian Institute of Soil Science, India, Tel 956 I I07426, Fax 0755-27333 I0, Email priyaguravnbss@gmail.com

Received: January 18, 2018 | Published: February 27, 2018

\section{Introduction}

In India, shrink-swell (Vertisols and Vertic Intergrades) soils are found mostly in the Peninsular region extending from $8^{\circ} 45^{\prime}$ to $26^{\circ} 0^{\prime} \mathrm{N}$ latitudes and $68^{\circ} 0^{\prime}$ to $83^{\circ} 45^{\prime} \mathrm{E}$ longitudes. These soils are developed in alluvium derived from weathering of Deccan basalt. ${ }^{1}$ The Vertisols and associated soils occupy about $116 \mathrm{Mha}$ in India. ${ }^{2}$ Vertisols dominated by smectites clay minerals, are generally rich in exchangeable or available potassium and give an impression of adequate $\mathrm{K}$ reserves for supplying potassium to plants. Potassium is known as a yield plus quality nutrient. It is involved in the working of a large number of enzymes, in the production and movement of photosynthates from leaves to storage organs, water economy and providing resistance against pests, diseases and stresses. Potassium is the seventh most abundant element in the earth's crust. Potassium, one of the 17 chemical elements required for plant growth and reproduction, is often referred to as the "the regulator" since it is involved with over 60 different enzyme systems in plants. Potassium aids plants in the production of starches, controls root growth, and regulates the opening and closing of pores in plant cells (called stomata), which is important for efficient water use. All plants require potassium, especially crops high in carbohydrates, such as potatoes.

In the present agriculture scenario, the net negative NPK balance is $19 \% \mathrm{~N}, 12 \% \mathrm{P}$, and $69 \% \mathrm{~K}$. The large proportion of $\mathrm{K}$ is partly because crops remove an average 1.5 times more $\mathrm{K}$ than $\mathrm{N}$ and $\mathrm{K}$ application through fertilizer is much lower than of $\mathrm{N}$ or P. However, total fertilizer nutrient consumption is increased especially $\mathrm{N}$ and $\mathrm{P}$ but the consumption of $\mathrm{K}$ fertilizers declined, which lead to wide gap in NPK ratio leading to mining of soil $\mathrm{K}$ and imbalance nutrition. ${ }^{3}$ In most of the intensive cropping system in India potassium balance is negative since the additions of $\mathrm{K}$ seldom match the $\mathrm{K}$ removals resulting in larger dependence on soil $\mathrm{K}$ supply. Under such conditions, there is greater pressure on non-exchangeable $\mathrm{K}$ for meeting the $\mathrm{K}$ requirements of the crops. Long-term intensive cropping, in the absence of $\mathrm{K}$ inputs, adversely affected the K supply to crop plants and consequently crop yields. ${ }^{4}$ Therefore, it is necessary to continuously emphasize the role and importance of $\mathrm{K}$ in crop production as balanced fertilizer use for the long term and sustainable use of agricultural lands. The removal of $\mathrm{K}$ needs to be balanced by adequate $\mathrm{K}$ inputs if a decline in soil fertility is to be avoided. In India, so far there was a general understanding that Vertisols are rich in $\mathrm{K}$ and there was no need for its application. However, with time it is likely that in some soils deficiency of $\mathrm{K}$ could occur due to continuous cropping, leaching loss, and soil erosion so on. This paper critically reviews the work done on soil $\mathrm{K}$ status and crop response to K fertilization.

\section{Potassium status in Indian soil}

Potassium is one of the three main pillars of balanced fertilizer use, along with N and P. while India is the third largest user of NPK fertilizers in the world, with current annual consumption at about 18 million tons (Mt) of $\mathrm{N}+\mathrm{P}_{2} \mathrm{O}_{5}+\mathrm{K}_{2} \mathrm{O}, \mathrm{K}$ constitutes only one seventh of the total. In the present agriculture scenario, the net negative NPK balance is $19 \% \mathrm{~N}, 12 \% \mathrm{P}$ and $69 \% \mathrm{~K}$. The large proportion for $\mathrm{K}$ is partly because crops remove an average 1.5 times more $\mathrm{K}$ than $\mathrm{N}$, and $\mathrm{K}$ application through fertilizer is much lower than that of $\mathrm{N}$ or P. The available K status generated in $1976{ }^{5}$ forms the benchmark information. Most of Indian soils are rated as medium to high in available $\mathrm{K}$ status. The nutrient index values based on more than 11 million soil test data ${ }^{5}$ shows that out of the 371 districts $76(21 \%)$ are low in potassium, $190(51 \%)$ are medium in potassium and $105(28 \%)$ are high in potassium. this data is based on $1 \mathrm{~N}$ ammonium extraction method, soils containing $130 \mathrm{~kg} \mathrm{~K}_{2} \mathrm{O} /$ ha were categorized as low, 130 to $335 \mathrm{~kg} \mathrm{~K}_{2} \mathrm{O} / \mathrm{ha}$ as medium and above $335 \mathrm{~kg} \mathrm{~K}_{2} \mathrm{O} / \mathrm{ha}$ as high. ${ }^{6}$

\section{Need for intensive research on potassium in Vertisols}

There are anomalies in crop response to applied potassium in different $\mathrm{K}$ fertility status of soil. Usually soils which contain less than $120 \mathrm{~kg} \mathrm{ha}^{-1} \mathrm{~K}\left(144 \mathrm{~kg} \mathrm{~K}_{2} \mathrm{O}\right)$ are rated as low in available $\mathrm{K}$, between 120 and $280 \mathrm{~kg} \mathrm{ha}^{-1} \mathrm{~K}\left(144-336 \mathrm{~kg} \mathrm{~K}_{2} \mathrm{O}\right)$ as medium and above 280 
$\mathrm{kg} \mathrm{ha}^{-1} \mathrm{~K}(336 \mathrm{~kg} \mathrm{~K} \mathrm{O})$ as high in available $\mathrm{K}^{6}{ }^{6}$ Unfortunately, these ratings limits are irrespective of crops or soils. For example, ${ }^{7}$ studied the response of two wheat varieties to potassium on farmer's field in shrink-swell soils. Though these soils were adequate in ammonium acetate extractable $\mathrm{K}$, crop responded to $30 \mathrm{~kg} \mathrm{ha}^{-1} \mathrm{~K}_{2} \mathrm{O}$. They have established a critical limit of $14.4 \mathrm{~kg} \mathrm{ha}^{-1} \mathrm{~K}$ water-soluble $\mathrm{K}$ but failed to establish a critical limit based on ammonium acetate $\mathrm{K}$. This indicates that ammonium acetate does not give proper indication of viability of $\mathrm{K}$ in shrink-swell soil. ${ }^{8}$ studied available $\mathrm{K}$ status and crop response at Jabalpur and indicated that Soybean started showing response to applied $\mathrm{K}$ when available $\mathrm{K}$ status reached to $316 \mathrm{~kg}$ ha${ }^{1}$. Whereas, wheat showed response to $\mathrm{K}$ even before. Similarly at Akola, sorghum started giving response to applied $\mathrm{K}$ at $324.4 \mathrm{~kg} \mathrm{ha}^{-1}$ whereas, a larger response in both the crops noted at available $\mathrm{K}$ status of $307.6 \mathrm{~kg} \mathrm{ha}^{-1}$. It means middle value of $\mathrm{K}$ status is $312 \mathrm{~kg} \mathrm{ha}^{-1}$ (average of 307.8 and 316.0) could be considered as critical value for Vertisols. This is greater than the threshold value $\left(280 \mathrm{~kg} \mathrm{ha}^{-1}\right)$ is being used for rating the soil as high in $\mathrm{K}$ status. Thus, for Vertisols there is need to increase the threshold value of $\mathrm{K}$ in soil to get the actual recommendation of $\mathrm{K}$ in soil to sustain the productivity and maximize benefit from applied nutrient. Under this situation, we have to revise of the ammonium acetate method is warranted which is used as soil test crop response all over the country. ${ }^{9,10}$

\section{Conclusion}

The available $\mathrm{K}$ status in Indian soils showed gradual decline from medium to low even in black soils. These trends were due to low K application by the farmers, imbalanced use of NPK fertilizers, misapplication of $\mathrm{K}$ recommendation leading to $\mathrm{K}$ deficiency in soils and crops. The present fertilizer recommendation is four decades old and still being used, warrants revision and revalidation. Also, we have to revise ammonium acetate method which is used as STCR all over the country.

\section{Acknowledgement}

None.

\section{Conflict of interest}

The authors declare that they have no conflict of interest.

\section{References}

1. Murthy RS, Bhattacharjee JC, Lande RJ, et al. Distribution, characteristics and classification of Vertisols. Trans. 12th International Congress of Soil Science Symposium Paper II, 1982;1(1):3-22.

2. Bhattacharyya T, Sarkar D, Pal DK. et al. Potassium status of Shrinkswell soils of India, vis-a-vis their mineralogy composition. International Symposium on Review and Refinement of fertilizers K Recommendation in Vertisols. 24-25, 2010 at NBSS and LUP, Nagpur. IPNI, IPI, NBSS and LUP, ICAR, India; 2010. p. 1-4.

3. Ramamurthy V, Naidu LGK, Ravindra Chary G, et al. Potassium Status of Indian Soils: Need for Rethinking in Research, Recommendation and Policy. International Journal of Current Microbiology and Applied Sciences. 2017;6(12):1529-1540.

4. Swarup A. Emerging soil fertility management issues for sustainable crop productivity in irrigated systems. Proceedings of National workshop held 2-4 April, 1998 at IISS, Bhopal. India; 1998. p. 54-68.

5. Ghosh AB, Hassan R. Available potassium status of Indian soils. Indian Society of Soil Science. Bulletin. 1976;10:1-5.

6. Muhr GR, Datta NP, Shankara Subramoney H, et al. Soil Testing in India. USAID, New Delhi; 1965. 120 p.

7. Solankey BS, Shinde DA, Yadav KS, eta al. Response of wheat to K application in shrink-swell soils in relation to water-soluble $\mathrm{K}$ contents. Journal of Potassium Research. 1992;7:9-19.

8. Muneshwar Singh, Wanjari RH. Potassium response and requirement in crops grown in Vertisols: Experiences from long term fertilizer experiments. Indian J Fert. 2012;8(3):26-32.

9. Rahanul Hassan. Potassium status of soils in India. Better Crops International. 2002;16(2):3-5.

10. Tandon HLS. Soil nutrient balance sheets in India: Importance, status, issues, and concerns. Better Crops India. 2007;1:15-91. 